\title{
Urgences
}

\section{Un signe...}

\section{Chantal Nadeau}

Numéro 13, mars 1986

\section{Éclats d'atelier}

URI : https://id.erudit.org/iderudit/025215ar

DOI : https://doi.org/10.7202/025215ar

Aller au sommaire du numéro

\section{Éditeur(s)}

Urgences

\section{ISSN}

0226-9554 (imprimé)

1927-3924 (numérique)

Découvrir la revue

\section{Citer ce document}

Nadeau, C. (1986). Un signe... Urgences, (13), 37-37.

https://doi.org/10.7202/025215ar d'utilisation que vous pouvez consulter en ligne.

https://apropos.erudit.org/fr/usagers/politique-dutilisation/ 


\section{Chantal Nadeau}

Un signe, un simple appel suscite un doute. Des rêves perdus, égarés, un oubli. II s'enfonce dans l'abî̀me. La grande, puante et lourde porte se referme. Le néant s'installe. Et soudainement dans la fumée, une force, un orage. Logiquement, un astre? ou un atome? un accès? ou un arrêt? Une froide pluie ruisselle. Inonde-t-elle l'active ville ahurie, assise sur l'arche? Harcèle-t-elle l'ombre, le jeune affolé, dérobé par I'asile? Succombe-t-il? Le malain rumine. Les idées, les rêves se bousculent. UN arôme? un fumet? II frissonne jusqu'au dedans du corps. S'exalter, s'empiffrer, s'assouvir pour s'évanouir. II frétille.

Au-delà du passé, de l'ennui, de la ruine: une image claire et réelle. II jubile. Une issue vioiée. Une envie, un désir ardent. Le chant, I'hymne, le faîte de la folie. Depuis le temps maudit, il bredouille. Un raton grignote, goulûment enivré. II savoure. Traqué, il déguerpit, replet.

Par les soirs, les rêves reviennent brusquement de l'oubli et le monde chavire. Des coups, le bruit fuyant des vents qui pénètrent inévitablement le corps replié, inerte. Des liens brisés, une route coupée depuis le souci jusqu'à l'ennui.

Un signe, un double appel ravive un doute. Une porte fermée, clouée et le voile redescend. Un geste souple, répété tout simple. L'idiot s'effondre sans force. Il régresse. Néant. 